\title{
O princípio do não-confisco e sua aplicabilidade nas multas sobre o débito de IPVA
}

\author{
The principle of non-confiscation and its applicability on the IPVA fines
}

\author{
Beatriz Piero Bon de Almeida ${ }^{1}$ \\ Rafael Resende Britto ${ }^{2}$
}

\section{Resumo}

\begin{abstract}
Elenca as características do Estado Democrático de Direito, discriminando algumas de suas consequências tributárias. Conceitua o princípio do não-confisco, apontando sua fundamentação constitucional e seus reflexos no sistema tributário nacional. Apresenta a regra matriz de incidência fiscal do IPVA, contornando suas principais características. Desenvolve o tema da aplicabilidade do princípio do nãoconfisco nas multas decorrentes do inadimplemento do Imposto sobre a Propriedade de Veículos Automotores. Tem por objetivo apresentar as posições doutrinárias e jurisprudenciais a respeito do tema, selecionando o entendimento que melhor se adequa aos princípios constitucionais tributários.
\end{abstract}

Palavras-chave: Principio do não-confisco. Multas. IPVA.

\begin{abstract}
It lists the characteristics of the Democratic Estate of Law, describing some of its tax consequences. Conceptualizes the principle of non-confiscation, pointing his constitutional groundsand their reflections in the national tax system. Displays the IPVA matrix rule of tax incidence, outlining its main features. Develops the theme of the applicability of the principle of non-confiscation in fines resulting from noncompliance on the Property Tax of Motor Vehicles. It aims to present the doctrinal and jurisprudential positions on the subject by selecting the understanding that best fits the tributaries constitutional principles.
\end{abstract}

Keywords: Principle of non-confiscation. Fines. IPVA.

\section{Introdução}

O presente trabalho tem por objeto o estudo do princípio do não confisco e da possibilidade de aplicação dos seus efeitos às multas decorrentes dos débitos do Imposto sobre Propriedade de Veículos Automotores - IPVA.

1 Concluiu a graduação na UEL em 2011, atualmente cursa pós graduação em Direito Constitucional Contemporâneo pelo Instituto de Direito Constitucional e Cidadania - IDCC.

2 Concluiu a graduação na UEL em 2011, atualmente cursa pós graduação em direito aplicado pela Escola da Magistratura do Paraná - EMAP. Ex-integrante do Projeto de Extensão do Departamento de Direito Público/UEL: "ECA aplicado à educação escolar" no período de 01/03/2008 à 01/12/2010. 
Em um primeiro plano, impende destacar o elo existente entre o princípio de proibição do confisco com o atual modelo de Estado, o Estado Democrático de Direito.

Abordar-se-ão os fundamentos e as disposições legais que fixaram o não-confisco como um princípio constitucional tributário, apresentando seu conceito e sua importância no ordenamento jurídico.

Na sequência, será apresentada a regra matriz de incidência fiscal do aludido imposto, detalhando-se suas características principais, tais como sujeito ativo, sujeito passivo, critério material, critério temporal, critério espacial, dentre outras.

De toda a sorte, convém avaliar se o princípio de vedação ao confisco tem sua aplicação restrita aos tributos ou se, de outro lado, é passível de ser aplicado no caso de incidência das multas tributárias.

Por derradeiro, a mesma avaliação de aplicabilidade será efetuada em relação ao tributo do IPVA, com ênfase as suas peculiaridades e com a colação dos entendimentos dos tribunais superiores.

Posto isso, o primeiro tópico versará sobre o contexto no qual se deu o reconhecimento do princípio do não-confisco, qual seja, o Estado Democrático de Direito.

\section{Do Estado Democrático de Direito}

Logo no primeiro artigo da Constituição Federal de 1988, positivou-se que a República Federativa do Brasil constitui-se em Estado Democrático de Direito.

Este novo modelo de Estado, antagônico em relação ao Estado totalitário do período militar, irradia características nos mais diversos ramos de atuação do governo e da sociedade, inclusive na esfera tributária.

Para que se compreendam as consequências dessa escolha do constituinte, faz-se mister o reconhecimento de suas características principais, destacando-se que a expressão “Estado Democrático de Direito" reúne as noções de 'Estado de Direito' e de 'Estado Democrático'.

O ponto de sustentação do Estado de Direito reside na submissão de governantes e governados ao direito, ou seja, a regras positivadas. Nessa opinião comunga Joaquim José Gomes Canotilho: 


\begin{abstract}
A expressão Estado de Direito é considerada uma fórmula alemã (Rechtsstaat). Ela aponta para algumas das idéias fundamentais já agitadas na Inglaterra, Estados Unidos e França. Acrescenta-Ihes, porém, outras dimensões. O Estado domesticado pelo direito é um Estado juridicamente vinculado em nome da autonomia individual ou, se se preferir, em nome da autodeterminação da pessoa. [...] Contra a idéia de um Estado de polícia que tudo regula a ponto de assumir como tarefa própria a felicidade dos súbditos, o Estado de direito perfila-se como um Estado de limites, restringindo a sua acção à defesa da ordem e segurança pública. [...] Compreende-se, assim, que qualquer intervenção autoritária sobre os dois direitos básicos - liberdade e propriedade - estivesse submetida à existência de uma lei do parlamento (CANOTILHO,1999, p. 09).
\end{abstract}

Em relação ao Estado Democrático, Zulmar Fachin (2008, p. 179) assevera que seu fundamento é a soberania popular. O vocábulo democrático aparece como um qualificativo do Estado, sendo que tal conteúdo deve inspirar não apenas os atos a serem praticados no âmbito do Estado, mas, inclusive, as relações entre particulares.

Superadas estas conceituações, o mesmo doutrinador enfatiza que o Estado Democrático de Direito não é apenas o resultado da união formal entre Estado de Direito e Estado Democrático, posto que, apesar de reunir os princípios do Estado Democrático e do Estado de Direito, apresenta um conceito novo, superando-os na medida em que requer um Estado de Justiça (FACHIN, 2008, p. 179-180).

Dentro destes contornos, José Afonso da Silva pondera:

\begin{abstract}
A democracia que o Estado Democrático de Direito realiza há de ser um processo de convivência social numa sociedade livre, justa e solidária (art. $3^{\circ}, 1$ ), em que o poder emana do povo, e deve ser exercido em proveito do povo, diretamente ou por representantes eleitos (art. $1^{\circ}$, parágrafo único); participativa, porque envolve a participação crescente do povo no processo decisório e na formação dos atos de governo; pluralista, porque respeita a pluralidade de idéias, culturas e etnias e pressupõe assim o diálogo entre opiniões e pensamentos divergentes e a possibilidade de convivência de formas de organização e interesses diferentes da sociedade; há de ser um processo de liberação da pessoa humana das formas de opressão que não depende apenas do conhecimento formal de certos direitos individuais, políticos e sociais, mas especialmente da vigência de condições econômicas suscetíveis de favorecer o seu pleno exercício. (SILVA, 2000, p. 123124)
\end{abstract}

Convém destacar, em complemento, que existe perfeita coerência entre a forma de governo da República e o Estado Democrático de Direito, figuras jungidas no artigo $1^{\circ}$ da Constituição brasileira de 1988.

Sobre as características da República, assinala Roque Antonio Carraza (2009, p. 6566) que República é o tipo de governo fundado na igualdade formal das pessoas, em que os 
detentores do poder político exercem-no em caráter eletivo, representativo, transitório e com responsabilidade. Enquanto nas Monarquias os poderes supremos são conferidos a uma única pessoa que age em nome próprio, nas Repúblicas, os supracitados poderes são atribuídos a uma coletividade de pessoas ou a seus representantes jurídicos. Ademais, não há distinções entre nobres e plebeus. Todos são cidadãos; não súditos.

Desse modo, em toda a organização da República Federativa do Brasil constituída em Estado Democrático de Direito, bem como nas relações da população residente neste território, e ainda na relação do contribuinte com o Fisco, aplicam-se os ideiais da democracia, exsurgindo, por consequência, os princípios da estrita legalidade, tipicidade tributaria, irretroatividade, bem como, o que será abaixo estudado, o princípio do não confisco.

\section{Princípio do não-confisco}

Dentro do ordenamento jurídico, as normas se dispõem de maneira hierárquica, formando uma verdadeira "pirâmide jurídica" (CARRAZA, 2009, p. 33). Considerando essa pirâmide, a Constituição de um Estado encontra-se no topo, vez que representa a Lei Fundamental Estatal.

Em decorrência disso, as normas infraconstitucionais devem respeitar o enunciado no texto constitucional, sob pena de haver a declaração de inconstitucionalidade. Nesse sentido, importante a lição de Roque Antonio Carraza:

[...] As normas jurídicas mais importantes encontram-se na Constituição. É ela que indica quem detém os poderes estatais, quais são estes poderes, como devem ser exercidos e quais os direitos e garantias que as pessoas têm em relação a eles (CARRAZA, 2009, p. 33).

Perceptível, portanto, a importância que as normas constitucionais possuem dentro de uma ordem jurídica, em especial, da ordem jurídica brasileira.

Inseridos nesse contexto, há os princípios constitucionais, que possuem ainda mais relevância. Importante destacar, inicialmente, que o termo princípio apresenta vários significados. No entanto, considerando uma acepção lógica, Miguel Reale apresenta seu conceito para o termo ora em análise: 
Restringindo-nos ao aspecto lógico da questão, podemos dizer que os princípios são 'verdades fundantes' de um sistema de conhecimento, como tais admitidas, por serem evidentes ou por terem sido comprovadas, mas também por motivos de ordem prática de caráter operacional, isto é, como pressupostos exigidos pelas necessidades da pesquisa e da praxis (REALE, 2002, p. 303).

Logo, mediante uma análise puramente lógica, tem-se que princípio é um enunciado considerado como base e fundamento para determinado campo do saber. Logo, ao estudar um determinado campo de conhecimento - o Direito -, com ênfase no Direito Tributário, o que se torna relevante é a análise dos denominados princípios constitucionais tributários.

A compreensão do ordenamento jurídico de qualquer Estado deve ser feita com base no estudo dos princípios que regem o texto constitucional, pois são aqueles que dão fundamento e condição de validade para toda a ordem jurídica estatal. Os princípios constitucionais serão identificados à medida que, ao analisar uma Constituição, for verificada qual a estrutura daquele Estado, bem como seus fundamentos e alicerces. Os princípios constitucionais, por apresentarem um caráter estrutural, são considerados superiores dentro da hierarquia de normas constitucionais.

Nesse sentido, Celso Ribeiro Bastos apresenta a idéia de princípios constitucionais:

Os princípios constitucionais são aqueles que guardam os valores fundamentais da ordem jurídica. Isto só é possível na medida em que estes não objetivam regular situações específicas, mas sim desejam lançar a sua força sobre todo o mundo jurídico. Alcançam os princípios esta meta à proporção que perdem o seu caráter de precisão de conteúdo, isto é, conforme vão perdendo densidade semântica, eles ascendem a uma posição que lhes permite sobressair, pairando sobre uma área muita mais ampla do que uma norma estabelecedora de preceitos. Portanto, o que o princípio perde em carga normativa ganha como força valorativa a espraiar-se por cima de um sem-número de outras normas (BASTOS apud ARAUJO, 2001, p. 59).

Os princípios constitucionais, dessa forma, apresentam-se como "regras-mestras dentro do sistema positivo" (ARAUJO, 2001, p. 58). Por esse motivo, são eles que indicam qual o caminho deve ser seguido pelo intérprete, ou seja, qual a norma que deve incidir em determinado caso.

Tratando dos princípios constitucionais em relação ao Direito Tributário, por àqueles dirigirem o modo de incidência de todas as normas jurídicas, também irão influir em relação às competências tributárias. Isso porque se a Constituição, e, em particular, os 
princípios constitucionais, são o fundamento de todo o ordenamento jurídico, por conseguinte também será a base do Direito Tributário.

A Constituição Federal de 1988, em seu Título VI (Da Tributação e do Orçamento), Capítulo I (Do Sistema Tributário Nacional), traz a competência tributária, ou seja, informa de que modo será distribuída a instituição dos tributos entre os entes políticos - União, Estados, Distrito Federal e Municípios.

No entanto, para exercício da competência tributária, o próprio texto constitucional estabelece alguns limites que devem ser respeitados pelos entes competentes. Assim, "a Constituição fixa vários balizamentos, que resguardam valores por ela reputados relevantes, com atenção especial para os direitos e garantias individuais" (AMARO, 2011, p. 128).

Resta demonstrado que há limitações ao poder de tributar. Isso significa dizer que ao exercer a sua respectiva competência tributária, o ente político não pode agir discricionariamente; deve observar as normas jurídicas que visam proteger os cidadãos e contribuintes de um possível arbítrio do poder estatal.

Vale destacar que as limitações ao poder de tributar encontram-se dispostas nos artigos 150 a 152 da Carta Magna de 1988, e são compostos pelos princípios constitucionais tributários e pelas imunidades tributárias.

Dentre os princípios que representam uma limitação ao poder de tributar encontrase o princípio do não-confisco.

Para melhor entendimento do princípio em apreço, por 'confisco' deve ser entendido "arresto, ou, apreensão, em favor do Fisco" (SIDOU, 2006, p. 195). Assim, confiscar é o ato de se retirar bens do particular em prol do Estado; é o "ataque à propriedade privada, pelo Estado, sem compensação ao proprietário" (HORVATH, 2002, p. 46).

No sistema jurídico tributário pátrio, o princípio do não-confisco está estabelecido no art. 150, IV, que enuncia: "Sem prejuízo de outras garantias asseguradas ao contribuinte, é vedado à União, aos Estados, ao Distrito Federal e aos Municípios utilizar tributo com efeito de confisco" (BRASIL, Constituição Federal, art. 150, IV).

Ao impedir que a tributação tenha por efeito o confisco, o que se veda é a ação estatal de se apossar de bens particulares, utilizando, para isso, a tributação como fundamento. 
Não há dúvidas acerca da natureza de prestação pecuniária inerente ao tributo. Como conseqüência dessa condição, com o pagamento de tributos, necessariamente haverá a transferência de recursos do indivíduo para o Estado. Desse modo, nos casos em que o ente político exerce sua competência tributária de maneira a observar os preceitos constitucionais, haverá uma tributação legal e, portanto, não confiscatória.

Nesse sentido, o doutrinador Luciano Amaro (2011, p. 168) ensina que o princípio em comento não pretende proteger a propriedade de modo absoluto, o que acabaria por anular totalmente o poder de tributar; seu objetivo, porém, é impedir que o Estado, mediante a cobrança de tributos, anule a riqueza privada.

O problema maior no estudo do princípio da vedação da tributação confiscatória reside no fato de ser esse um "conceito indeterminado", como menciona Estevão Horvath (2002, p. 34). Isso porque saber o que é ou não confiscatório nem sempre é tarefa simples.

O que para uns tem efeito de confisco, para outros, apresenta-se como uma cobrança legítima de tributo. Tal dificuldade em estabelecer o que teria efeito confiscatório surge em razão da falta de precisão constitucional acerca do princípio em tela. Não se vislumbra, no texto constitucional, um limite concreto que torne fácil a visualização do confisco em determinada situação fática.

Desta feita, a relevância do princípio do não-confisco reside no fato de apresentarse como uma limitação ao legislador, no momento de exercer sua atividade de legislar acerca da tributação, bem como limita o julgador, que, diante do caso concreto, deverá sempre levar em consideração o efeito do não-confisco, coibindo sua incidência.

Mesmo sendo difícil identificar o efeito de confisco, esse princípio jamais poderá deixar de ser observado; se for verificado que em decorrência da tributação o Estado está retirando bens do indivíduo de maneira ilegal e abusiva, a instituição do tributo deve ser declarada incompatível com o sistema jurídico tributário, vez que não seguiu os ditames constitucionais.

Desse modo, o princípio do não-confisco possui duas características fundamentais e complementares, quais sejam, a limitação ao poder de tributar e a proteção dos direitos dos cidadãos e contribuintes. 


\title{
3.1 Correlação entre o Princípio do Não-Confisco e o IPVA
}

Já devidamente caracterizado, não há divergências doutrinárias a respeito da aplicabilidade do princípio do não-confico com os tributos de maneira geral, logo, por coerência, o aludido princípio pode se correlacionar com o IPVA.

Entretanto, novamente destaca-se a dificuldade na definição de elementos balisadores concretos que permitam a classificação confiscatória de um tributo. Nessa senda, o então Senador Fernando Henrique Cardoso argumentava:

\begin{abstract}
Será confiscatório o imposto que, sem levar em conta reais despesas do contribuinte, acaba tributando como renda líquida valor que na realidade é renda bruta e por isso fica o contribuinte em déficit para cuidar de suas necessidades, depois que faz o pagamento do imposto dele exigido? Talvez a solução esteja na criação de um rito processual posto à disposição dos contribuintes, de modo que cada um, julgando-se atingido por confisco em virtude da tributação por um ou por vários impostos que tenha de suportar, possa ter como ajustar a carga tributária que entende confiscatória. (MARTINS; BASTOS, 1990, p. 162-163).
\end{abstract}

Dessa maneira, sem definir critérios fixos, o IPVA não pode gravar de modo desproporcional o patrimônio do proprietário de veículo automotor, ferindo sua capacidade contributiva com o fim de suportar a repartição das depesas públicas, absorvendo parte considerável de sua propriedade pela via da tributação.

Considerando que a base de cálculo do IPVA será sempre o valor do veículo automotor, a cobrança abusiva do tributo só pode ser proveniente da estipulação de alíquotas exorbitantes definidas em lei estadual.

Na realidade prática, verifica-se que as alíquotas estão balizadas entre 2 e 4 por cento, assim, observa-se que elas não atingem uma parcela expressiva do bem, contudo, caso os Estados-membros aumentem consideravelmente esses percentuais, os contribuintes poderiam, sem dúvidas, avocarem o princípio constitucional do não-confisco tanto no âmbito administrativo quanto no judicial.

Neste ponto, é necessária a compreensão da regra matriz de incidência fiscal do Imposto sobre a Propriedade de Veículos Automotores. 


\section{Regra matriz de incidência fiscal do IPVA}

O Imposto sobre a Propriedade de Veículos Automotores, assim como os demais impostos, é classificado pela doutrina e pela legislação pátria como espécie do gênero 'tributo'.

Nessa esteira, o vocábulo tributo é explicitado no artigo $3^{\circ}$ do Código Tributário Nacional: "Tributo é toda prestação pecuniária compulsória, em moeda ou cujo valor nela se possa exprimir, que não constitua sanção de ato ilícito, instituída em lei e cobrada mediante atividade administrativa plenamente vinculada" (BRASIL, Código Tributário Nacional, art. $3^{\circ}$ ).

Maria Luiza Vianna Pessoa de Mendonça ensina que o dever fundamental de pagar tributos:

[...] além de sua dimensão subjetiva que se traduz na sujeição passiva do indivíduo perante o Estado, também apresenta uma dimensão objetiva de valor, que pode se expressar na idéia de que os custos necessários para a existência, subsistência e o funcionamento da máquina estatal bem assim para possibilitarem o exercício da solidariedade dos membros da comunidade estatal mediante a implementação dos direitos sociais devem ser repartidos entre todos os cidadãos que demonstrem capacidade contributiva para suportá-los (FISCHER, 2004, p. 241).

Segundo Paulo de Barros Carvalho (2009, p. 278), entende-se que a regra-matriz de incidência tributária, por ser uma regra de comportamento, disciplina de maneira preordenada a conduta do sujeito devedor da prestação fiscal perante o sujeito pretensor, titular do direito de crédito.

A regra-matriz permite a separação do antecedente (norma geral e abstrata) da hipótese de incidência tributária, do consequente (norma individual e concreta), a fim de que a tipicidade entre ambos seja aferida no futuro.

Pode-se afirmar, em linhas gerais, que a ocorrência de uma determinada hipótese tributária depende da presença fática dos critérios temporal, espacial e material, implicando na existência de uma relação jurídica tributária entre um sujeito ativo (credor do tributo) e um sujeito passivo (devedor do tributo).

Em caso de inadimplemento por parte do sujeito passivo - não pagamento do tributo -, há incidência de uma sanção que, no caso do direito tributário, se reflete nas multas. 
Dessa forma, a regra-matriz de incidência fiscal pode ser utilizada para o estudo dos tributos, sendo que, no presente estudo, sua função será conduzir o estudo do IPVA.

Da leitura do art. 155, III, da Carta Magna de 1988, extrai-se que compete aos Estados e ao Distrito Federal instituir imposto sobre a propriedade de veículos automotores. Assim, são esses os sujeitos ativos do IPVA.

Para a ocorrência da hipótese tributária, de nodal importância que o contribuinte realize o critério material que, no caso em apreço, se traduz em ser proprietário de veículo automotor, ou seja, de qualquer veículo que se movimente por autopropulsão e se destina ao transporte de pessoas ou coisas.

Segundo a doutrina majoritária, o critério temporal do IPVA, por ser o momento em que o critério material considera-se ocorrido, se subdivide em dois. Para proprietários de carros novos, o critério é a data da compra do carro. Em se tratando de carro usado, de outra forma, o critério foi fixado pelo legislador como sendo o dia primeiro de janeiro de cada ano.

No que concerne ao critério espacial, o mesmo é importante para a firmação do ente federativo que figurará como sujeito ativo e, considerando que não existem normas gerais que disciplinam o IPVA e que o contribuinte tem a opção de escolher um de seus domicílios para registrar o veículo, há uma verdadeira guerra fiscal entre os Estadosmembros, tema que não será discutido nesse estudo.

Como narrado em epígrafe, com a coadunação desses três critérios, pode-se afirmar a ocorrência da hipótese tributária que, por consequência, acarreta na formação da relação jurídica tributária entre o proprietário do veículo automotor e o Estado-membro do respectivo registro do bem.

Essa relação tem por objeto a obrigação de pagar o tributo do IPVA, que se constitui pelo resultado da multiplicação da base de cálculo (valor do automóvel) por uma alíquota a ser definida na lei estadual de cada ente.

Superado esse breve estudo da regra matriz do IPVA, é possível verificar-se, primordialmente, a distinção entre o tributo - objeto da obrigação de pagar proveniente da relação jurídica tributária entre o Fisco e o contribuinte, que se dá após a ocorrência da hipótese tributária -, e a multa, que se configura como forma de sanção ao contribuinte inadimplente. 


\section{Aplicabilidade do princípio do não-confisco às multas decorrentes do inadimplemento do IPVA}

Como já mencionado, o princípio do não-confisco visa à proteção da propriedade privada, tendo em vista que coíbe a tributação que alcance de maneira absoluta toda renda ou patrimônio do indivíduo. Nesse sentido, é mister mencionar que o princípio em análise, disposto no art. 150, inciso IV, da Constituição Federal coaduna com o dispositivo 170, inciso II, da Carta Magna, que garante à proteção da propriedade privada.

A disposição constitucional acerca do princípio do não-confisco é cristalina ao afirmar que sua aplicação refere-se aos tributos. Em decorrência de tal situação, não há qualquer dúvida, tanto na doutrina, como na jurisprudência, sobre a aplicabilidade do princípio que veda o confisco nos tributos. Em que pese haja dificuldade em saber, precisamente, o que teria ou não efeito confiscatório, por ser esse um termo vago, há a certeza de que não se pode instituir ou majorar os tributos de modo que esses violem os preceitos constitucionais e aniquilem a propriedade privada.

Se em relação aos tributos a questão confiscatória é pacificada, o mesmo não se pode dizer em relação às multas tributárias.

Para melhor entendimento do tema, deve ser entendido, inicialmente, que tributo e multa são instituições distintas. Isso porque enquanto o tributo é uma prestação pecuniária decorrente de ato lícito (conforme se infere da interpretação do art. 3o do CTN), a multa é proveniente de um ato ilícito.

A multa, portanto, vai incidir nos casos em que houver um descumprimento das obrigações tributárias; o fato gerador da multa reside na ilicitude, na ocorrência de infração no campo tributário.

Para ilustrar a diferença entre o tributo e a multa, há o ensinamento de Hugo de Brito Machado:

O tributo se distingue da penalidade exatamente porque esta tem como hipótese de incidência um ato ilícito, enquanto a hipótese de incidência do tributo é sempre algo lícito. Não se conclua, por isto, que um rendimento auferido em atividade ilícita não está sujeito ao tributo. Nem se diga que admitir a tributação de tal rendimento seria admitir a tributação do ilícito. É importante, neste particular, a distinção entre hipótese de incidência que é a descrição normativa da situação de fato, e fato gerador do tributo [...]. Quando se diz que o tributo não constitui sanção de ato ilícito, isto quer dizer que a lei não pode incluir na hipótese de incidência tributária 
o elemento ilicitude. Não pode estabelecer como necessária e suficiente à ocorrência da obrigação de pagar um tributo uma situação que não seja lícita. Se o faz, não está instituindo um tributo, mas uma penalidade. Todavia, um fato gerador de tributo pode ocorrer em circunstâncias ilícitas, mas essas circunstâncias são estranhas à hipótese de incidência do tributo, e por isso mesmo irrelevantes do ponto de vista tributário (MACHADO, 2003, p. 59-60).

Dessa maneira, o contribuinte que não efetuou o pagamento do tributo, receberá a sanção da multa, que tem por finalidade punir aquele que não cumpriu com seu dever de pagar para o Fisco o valor do tributo, para que assim, seja evitada e desestimulada a sonegação fiscal.

Feita a distinção necessária acerca do tributo e da multa, surge a indagação acerca da aplicabilidade do efeito confiscatório na multa que provém do inadimplemento tributário.

Aqui surge divergência; doutrina e jurisprudência ainda não consolidaram entendimento em relação à questão levantada. Por isso mesmo, são encontrados pontos de vistas diversos sobre o tema.

Na doutrina, há cisão entre os que acreditam na aplicabilidade do princípio do nãoconfisco às multas e àqueles que acreditam que às multas são divorciadas da vedação ao efeito confiscatório. A razão de ser dessa divergência reside na própria natureza diversa do tributo e da multa: enquanto o primeiro possui uma natureza de arrecadação, a multa representa uma sanção.

Por isso mesmo, àqueles que, como Estevão Horvath, sustentam a inaplicabilidade do princípio do não-confisco às multas, argumentam que, em razão da diferença jurídica entre o tributo e a multa, "os princípios que regem as infrações são distintos daqueles que informam a tributação" (HORVATH, 2002, p. 114).

Segue o supracitado autor na defesa da inaplicabilidade do princípio da vedação do efeito confiscatório às multas:

Em primeiro lugar, a multa é penalidade imposta pela legislação, decorrente do incumprimento de algum dever ou obrigação por parte de que a ela se assujeita. Em termos mais técnicos, a norma sancionadora tem como hipótese exatamente o descumprimento de outra norma que impusera determinada conduta. [...] Noutro giro, tributo não é multa e o princípio da não-confiscariedade proclamado pelo art. 150,IV da Constituição reporta-se àquele e não a esta (HORVATH, 2002, p. 114). 
Na jurisprudência, também são encontradas decisões que apontam que as multas devem ter regime jurídico próprio, e, por isso, o princípio do não-confisco, que é um princípio típico dos tributos, não deve incidir sobre as penalidades pecuniárias.

Para demonstrar como a afirmação acima corresponde com algumas decisões judiciais, há o julgado abaixo:

TRIBUTÁRIO E PROCESSUAL CIVIL - AÇÃO ANULATÓRIA DE DÉBITO FISCAL SONEGAÇÃO - MULTA - PERCENTUAL - LEGALIDADE - JUROS MORATÓRIOS - TAXA SELIC - MATÉRIA NÃO VEICULADA NA INICIAL - EXAME- VEDAÇÃO.

1. A regra prevista no artigo 150 , inciso IV, da Constituição Federal, que veda a utilização do tributo com efeito de confisco, não atinge o percentual das multas fixadas para o caso de descumprimento da obrigação tributária, uma vez que se trata de penalidade imposta àqueles que, de alguma forma, venham a causar prejuízos ao erário, em razão de determinada infração prevista em lei.

2. O pedido inicial restringe a lide, não devendo o magistrado emitir provimento jurisdicional diverso daquele pleiteado pela parte, sob pena de nulidade. Assim, verificado que a matéria relativa à aplicação da taxa selic não foi ventilada na petição inicial, nem enfrentada na $r$. sentença hostilizada, resta inviabilizado o seu exame pelo tribunal.

3. Recurso conhecido e não provido. (BRASIL, Tribunal de Justiça do Distrito Federal, 2006) (grifo nosso)

Muito embora haja essa posição em considerar a inaplicabilidade do princípio nãoconfisco às multas tributárias, a doutrina e a jurisprudência que se posicionam de maneira contrária vêm ganhando cada vez mais força.

Assim, aqueles que sustentam a vedação do efeito confiscatório às multas, utlizam como fundamento o fato de que o contribuinte, ainda que inadimplente, deve estar protegido contra ao arbítrio estatal.

Portanto, para os que defendem a aplicabilidade do princípio do não- confisco às multas tributárias, o que deve ser feito é a utilização da razoabilidade. Assim, a finalidade das multas tributárias deve ser punir o contribuinte faltoso, abastecendo os cofres públicos, e não confiscar o patrimônio privado.

É imprescindível que a penalidade aplicada tenha o condão de representar uma quantia que, de fato, sancione o devedor tributário, para que esse se sinta desestimulado ao inadimplemento posterior. No entanto, em razão disso, não pode o Fisco utilizar-se da multa como maneira de apropriar-se indevidamente dos bens particulares. Por isso, a multa deve ser razoável, no sentido de preservação do patrimônio do indivíduo. 
O que não pode deixar de ser mencionado é que a aplicação da razoabilidade pode ser fácil na teoria. Todavia, na análise do caso concreto, mostra-se dificílima a tarefa de determinar se a multa tem caráter tão-somente punitivo ou se, juntamente com a punição, apresenta efeito confiscatório. No entanto, apesar da dificuldade existente, não pode o intérprete deixar de verificar se a penalidade é ou não razoável, sob pena de violação de um direito do contribuinte, pois, ainda que inadimplente, seus direitos devem ser respeitados.

Na doutrina, como adeptos à aplicabilidade do princípio do não-confisco às multas, tem-se os doutrinadores Eduardo Rocha Dias e Natércia Sampaio Siqueira:

Por outra, embora as multas não sejam devidas em razão da capacidade contributiva, mas de um ilícito, a Constituição não permite, com exceção da matéria penal e de outras situações dentre as quais não se encontra o ilícito tributário, que haja sanção que inviabilize a propriedade, configurando o confisco (DIAS; SIQUEIRA, 2004, p. 130)

Seguindo o mesmo ensinamento dos doutrinadores acima mencionados, há o seguinte entendimento jurisprudencial:

AÇÃO DIRETA DE INCONSTITUCIONALIDADE. §§ 2. E 3. DO ART. 57 DO ATO DAS DOSPOSIÇÕES CONSTITUCIONAIS TRANSITÓRIAS DA CONSTITUIÇÃO DO ESTADO DO RIO DE JANEIRO. FIXAÇÃO DE VALORES MÍNIMOS PARA MULTAS PELO NÃORECOLHIMENTO E SONEGAÇÃO DE TRIBUTOS ESTADUAIS. VIOLAÇÃO AO INCISO IV DO ART. 150 DA CARTA DA REPÚBLICA.

A desproporção entre $O$ desrespeito à norma tributária e sua conseqüência jurídica, a multa, evidencia o caráter confiscatório desta, atentando contra o patrimônio do contribuinte, em contrariedade ao mencionado dispositivo do texto constitucional federal. Ação julgada procedente. (BRASIL, Supremo Tribunal Federal, 2003) (grifo nosso)

Como verificado na decisão acima, julgando a Ação Direta de Inconstitucionalidade n. 551-1, o Supremo Tribunal Federal decidiu que, ainda que as multas diferenciem-se dos tributos, o princípio do não-confisco deve a elas ser aplicado, vez que deve haver proporcionalidade entre a violação da obrigação jurídica tributária, e a sua conseqüência jurídica, qual seja, a multa (BRASIL, Supremo Tribunal Federal. ADI no 551/RJ, 2003).

Corroborando com o julgado acima, também há uma outra Ação Direta de Inconstitucionalidade que traz a tese de que as multas devem respeitar o princípio constitucional do não-confisco: 
AÇÃO DIRETA DE INCONSTITUCIONALIDADE - LEI № 8.846/94 EDITADA PELA UNIÃO FEDERAL - ALEGAÇÃO DE OFENSA AOS POSTULADOS CONSTITUCIONAIS DA FEDERAÇÃO E DA SEPARAÇÃO DE PODERES - INOCORRÊNCIA - EXERCÍCIO, PELA UNIÃO FEDERAL, DE SUA COMPETÊNCIA IMPOSITIVA, COM ESTRITA OBSERVÂNCIA DOS LIMITES QUE DEFINEM ESSA ATRIBUIÇÃO NORMATIVA - DIPLOMA LEGISLATIVO QUE NÃO USURPA A ESFERA DE COMPETÊNCIA TRIBUTÁRIA DOS ESTADOS-MEMBROS E DOS MUNICÍPIOS - LEGITIMIDADE DO PODER REGULAMENTAR DEFERIDO AOS MINISTROS DE ESTADO -ATRIBUIÇÃO REGULAMENTAR DE SEGUNDO GRAU QUE POSSUI EXTRAÇÃO CONSTITUCIONAL (CF, ART. 87, PARÁGRAFO ÚNICO, II) - INOCORRÊNCIA DE OUTORGA, PELA LEI № 8.846/94, DE DELEGAÇÃO LEGISLATIVA AO MINISTRO DA FAZENDA - PODER REGULAMENTAR SECUNDÁRIO DESVESTIDO DE CONTEÚDO NORMATIVO PRIMÁRIO - TRANSGRESSÃO, NO ENTANTO, PELA LEI № 8.846/94 (ART. 3 E SEU PARÁGRAFO ÚNICO), AO PRINCÍPIO CONSTITUCIONAL DA NÃO-CONFISCATORIEDADE TRIBUTÁRIA - SUSPENSÃO CAUTELAR DA EFICÁCIA DE TAL PRECEITO LEGAL - MEDIDA CAUTELAR DEFERIDA, EM PARTE. A TRIBUTAÇÃO CONFISCATÓRIA É VEDADA PELA CONSTITUIÇÃO DA REPÚBLICA

É cabível, em sede de controle normativo abstrato, a possibilidade de o Supremo Tribunal Federal examinar se determinado tributo ofende, ou não, o princípio constitucional da não-confiscatoriedade consagrado no art. 150, IV, da Constituição da República. Hipótese que versa o exame de diploma legislativo (Lei 8.846/94, art. 3ํ e seu parágrafo único) que instituiu multa fiscal de $300 \%$ (trezentos por cento). A proibição constitucional do confisco em matéria tributária - ainda que se trate de multa fiscal resultante do inadimplemento, pelo contribuinte, de suas obrigações tributárias - nada mais representa senão a interdição, pela Carta Política, de qualquer pretensão governamental que possa conduzir, no campo da fiscalidade, à injusta apropriação estatal, no todo ou em parte, do patrimônio ou dos rendimentos dos contribuintes, comprometendo-lhes, pela insuportabilidade da carga tributária, o exercício do direito a uma existência digna, ou a prática de atividade profissional lícita ou, ainda, a regular satisfação de suas necessidades vitais básicas. - O Poder Público, especialmente em sede de tributação (mesmo tratando-se da definição do "quantum" pertinente ao valor das multas fiscais), não pode agir imoderadamente, pois a atividade governamental acha-se essencialmente condicionada pelo princípio da razoabilidade que se qualifica como verdadeiro parâmetro de aferição da constitucionalidade material dos atos estatais. (BRASIL, Supremo Tribunal Federal, 1998) (grifo nosso)

Pois bem, analisando as duas posições existentes - a que aceita a aplicabilidade do princípio em apreço às multas e aquela que não aceita -, perceptível que a posição mais acertada é a que considera que as multas não podem ter efeito confiscatório. Além dos argumentos acima citados em defesa dessa posição, o que deve ser entendido é que, apesar do art. 150, inciso IV, da Constituição Federal fazer menção, quando trata da vedação ao confisco, apenas ao tributo, a interpretação desse dispositivo deve ser feita de maneira sistemática.

Com efeito, o princípio do não-confisco deve abranger a obrigação tributária como um todo. E conforme se extrai do artigo 113, do Código Tributário Nacional, a multa também está compreendida em tal obrigação: 
Art. 113. A obrigação tributária é principal ou acessória.

§ 1 A obrigação principal surge com a ocorrência do fato gerador, tem por objeto o pagamento de tributo ou penalidade pecuniária e extingue-se juntamente com o crédito dela decorrente.

§ 2 A obrigação acessória decorrente da legislação tributária e tem por objeto as prestações, positivas ou negativas, nela previstas no interesse da arrecadação ou da fiscalização dos tributos.

§ 3ㅇ A obrigação acessória, pelo simples fato da sua inobservância, converte-se em obrigação principal relativamente à penalidade pecuniária. (BRASIL, Código Tributário Nacional, art. 113) (grifo nosso)

Desta feita, quando o Fisco se utiliza da multa como modo de apropriação abusiva de bens do indivíduo, há afronta a um ditame inconstitucional, ainda que de forma indireta. Quando se aplica o princípio do não-confisco às sanções pecuniárias, não se busca retirar a natureza sancionatória da multa; o principal escopo da aplicação desse princípio é fazer com que a multa seja razoável e equivalente à infração tributária cometida. Assim, a multa com caráter não-confiscatório, ao mesmo tempo, pune o inadimplente, mas resguarda sua propriedade privada da invasão violenta do Fisco, compatibilizando-se com a previsão constitucional.

Analisando agora o tema sob a ótica das multas decorrentes do inadimplemento do IPVA, deve ser entendido que os mesmos critérios de razoabilidade do valor da multa e de seu caráter apenas sancionatório devem ser aplicados.

O IPVA, por ser um imposto que recai sobre o patrimônio, tem ainda mais relação com a vedação ao efeito confiscatório, que, como já dito, visa proteger a propriedade privada. Por isso mesmo, os impostos sobre o patrimônio "são, talvez, o que vem em primeiro lugar à mente, quando se fala de proibição de tributo confiscatório" (HORVATH, 2002, p. 125).

Quando ocorre o inadimplemento do IPVA, conseqüentemente, será aplicada à multa sancionatória. Pelo que se inferiu da seguinte pesquisa, às multas tributárias deve ser aplicado o princípio do não-confisco. Mas, surge a indagação: de que modo será feita tal incidência?

O princípio do não-confisco não apresenta, em sua disposição constitucional, uma porcentagem exata para determinar até que ponto o tributo seria legítimo. Portanto, em relação aos impostos e multas, em especial, a multa proveniente do não pagamento do IPVA, não há um quantum preciso para se aferir o que seria o efeito confiscatório. 
Certo é que a jurisprudência vem tentando definir o que seria possível para cobrança de multas tributárias, sem que houvesse o desrespeito ao art. 150, inciso IV da Constituição Federal.

No caso do Imposto sobre a Propriedade de Veículos Automotores, há entendimento de que, no caso do sujeito passivo da relação tributária descumprir os seus deveres, seria até mesmo possível uma multa que correspondesse à $100 \%$ do valor do débito do IPVA, sem que houvesse o efeito proibido constitucionalmente. Desse modo, importante a transcrição do julgado:

RECURSO ORDINÁRIO CONSTITUCIONAL EM MANDADO DE SEGURANÇA. IPVA ATRASADO. INCIDÊNCIA DE MULTA DE 100\% SOBRE O VALOR DA EXAÇÃO. ALEGAÇÃO DE CONFISCO.

I - A multa aplicada no campo tributário deve seguir os mesmos princípios existentes para este ramo do direito, pois, apesar de não ser tributo, restringe o mesmo direito fundamental que este, que é a propriedade. Assim, a proibição contida no art. 150, IV, da Constituição Federal, de instituição de tributo com efeito de confisco, também se aplica às multas decorrentes da exação. Precedente do STF: ADI n. 1075/MC, Rel. Min. CELSO DE MELLO, DJ de 17/06/98.

II - Não configura confisco, entretanto, a aplicação de multa de $100 \%$ sobre débito de IPVA, visto que a alíquota deste imposto, incidente sobre o valor venal do veículo, atinge parcela pouco expressiva do bem.

III - Recurso ordinário improvido. (BRASIL, Superior Tribunal de Justiça, 2009) (grifo nosso)

Como se percebe da decisão do Superior Tribunal de Justiça acima colacionada, foi decidido que a multa sobre o débito do IPVA pode incidir sobre a totalidade dos valores devidos. A fundamentação da decisão foi de que como as alíquotas do IPVA são de aproximadamente $5 \%$, elas atingem uma parcela pouco expressiva do bem. Assim, no caso em análise, foi decidido que como a quantia devida pelo IPVA era razoável de ser paga pelo contribuinte faltoso, então, o pagamento de $100 \%$ sobre esse débito não era desproporcional ou confiscatório (BRASIL, Superior Tribunal de Justiça, 2009).

Vislumbra-se, portanto, que a decisão acerca da multa a ser cobrada sobre o IPVA não pago, no caso em tela, tomou por base a razoabilidade, já mencionada no decorrer dessa pesquisa.

Em relação ao IPVA, que por ser um imposto sobre veículo automotor é intimamente vinculado ao princípio que protege a propriedade privada (não-confisco), deve- 
se cuidar ainda mais para que a sua cobrança e a instituição de suas multas não propiciem abusos e ilegalidades fiscais.

Como há a ausência de parâmetros delimitadores no Direito Tributário Brasileiro acerca do aspecto confiscatório, quando houver a análise de um determinado caso concreto, o julgador deve sempre ter em mente que, mesmo no caso dos contribuintes inadimplentes, os direitos fundamentais destes devem ser resguardados. Portanto, a multa deve puni-lo, mas não agredir substancialmente seu patrimônio ou propriedade.

\section{Conclusão}

O Estado Democrático de Direito, além de limitar a atuação do poder estatal por meio de leis, garante que tais leis sejam emanadas da vontade popular, sendo que a Constituição Federal tem o povo como soberano.

Essa nova concepção de Estado, pautada em diversos princípios constitucionais e nos direitos fundamentais da pessoa humana, irradiou características nos mais diversos ramos da sociedade e do direito, e, dentre eles, destaca-se o direito tributário.

O princípio do não-confisco, por ser uma limitação ao poder de tributar do Estado reconhecida constitucionalmente, garante aos indivíduos a preservação de seu patrimônio, com a proibição de fixação de tributos abusivos.

Nesse diapasão, tal princípio tem sua aplicabilidade reconhecida no Imposto sobre a Propriedade de Veículos Automotores, preservando os direitos dos sujeitos passivos desse imposto, que devem ter condições de suportar o tributo sem grandes prejuízos próprios.

Impende destacar a dificuldade em estipular elementos balizadores para a caracterização do confisco, sendo necessária a verificação da realidade prática, tarefa que, por muitas vezes, incumbe ao aplicador do Direito.

Inexistindo divergências doutrinárias quanto à aplicabilidade da vedação ao confisco nos tributos, o melhor entendimento consiste na extensão de tal princípio, com uma exegese em consonância com a Carta Constitucional, às multas, que divergem dos tributos por serem provenientes de atos ilícitos do contribuinte, primordialmente, o não pagamento do tributo. 
Dentro do contexto IPVA, o contribuinte inadimplente deve ser protegido da tributação confiscatória tanto no momento da ocorrência da hipótese tributária, quanto na ocasião da estipulação da multa pelo inadimplemento.

Certamente, a aplicação do princípio do não-confisco às multas decorrentes do débito do IPVA contribui para a formação do Estado Democrático de Direito que, com a tributação razoável, terá atingido a função de promover a dignidade, a igualdade e a solidariedade.

\section{Referências}

AMARO, Luciano. Direito tributário brasileiro. 17. ed. São Paulo: Saraiva, 2011.

ARAUJO, Luiz Alberto David. Curso de direito constitucional. 4. ed. São Paulo: Saraiva, 2001

BRASIL. Constituição (1988). Vade Mecum compacto. São Paulo: Saraiva, 2009.

. Código Tributário Nacional. Vade Mecum compacto. São Paulo: Saraiva, 2009.

, Superior Tribunal de Justiça. Recurso em Mandado de Segurança n. 29.302.

Recorrente: Albertino Ferreira Peres. Recorrido: Estado de Goiás. Relator: Ministro Francisco Falcão. Brasília, 16 de junho de 2009. Disponível em:

<http://www.jusbrasil.com.br/filedown/dev2/files/JUS2/STJ/IT/RMS_29302_GO_126030577 3287.pdf>. Acesso em: 08 nov. 2011.

, Supremo Tribunal Federal. Ação Direta de Inconstitucionalidade no 551-1/Rio de Janeiro. Requerente: Governador do Estado do Rio de Janeiro. Requerido: Assembléia Legislativa do Estado do Rio de Janeiro. Relator: Ministro Ilmar Galvão. Brasília, 14 de fevereiro de 2003. Disponível em:

<http://www.jusbrasil.com.br/filedown/dev0/files/JUS2/STF/IT/ADI_551_RJ\%20_24.10.2002 .pdf>. Acesso em: 09 nov. 2011.

Supremo Tribunal Federal. Ação Direta de Inconstitucionalidade no 1.075 1/Distrito Federal. Requerente: Confederação Nacional do Comércio. Requerido: Congresso Nacional. Relator: Ministro Celso de Mello. Brasília, 1 de junho de 1998. Disponível em: $<$ http://redir.stf.jus.br/paginadorpub/paginador.jsp?docTP=AC\&docID=392114). Acesso em: 09 nov. 2011.

Tribunal de Justiça do Distrito Federal. Apelação Cível no 2004.01.1.088248-9. Apelante: Jãó Distribuidora de Bebidas Ltda. Apelado: Distrito Federal. Relator: Des. Humberto Adjuto Ulhôa. Brasília, 29 de novembro de 2006. Disponível em: 
$<$ http://tjdf19.tjdft.jus.br/cgi-

bin/tjcgi1?DOCNUM=1\&PGATU=1\&I=20\&ID=62410,64318,12759\&MGWLPN=SERVIDOR1\&N

XTPGM=jrhtm03\&OPT=\&ORIGEM=INTER>. Acesso em: 07 nov. 2011.

CANOTILHO, Joaquim José Gomes. Estado de Direito. Disponível em:

<http://geocities.ws/b2centaurus/livros/c/Canotilhopdf.pdf>. Acesso em: 29 out. 2011.

CARRRAZA, Roque Antonio. Curso de direito constitucional tributário. 25. ed. São Paulo: Malheiros Editores, 2009.

CARVALHO, Paulo de Barros. Curso de direito tributário. 21. ed. São Paulo: Saraiva, 2009.

DIAS, Eduardo Rocha; SIQUEIRA, Natercia Sampaio. Sanções administrativas tributárias: uma tentativa de enquadramento constitucional. In: MACHADO, Hugo de Brito. Sanções administrativas tributárias. São Paulo: Dialética, 2004.

FACHIN, Zulmar. Curso de direito constitucional. 3. ed. rev., atual. e ampl. São Paulo: Método, 2008.

FISCHER, Octavio Campos (Coord). Tributos e direitos fundamentais. São Paulo: Dialética, 2004.

HORVATH, Estevão. O princípio do não-confisco no direito tributário. São Paulo: Dialética, 2002.

MACHADO, Hugo de Brito. Curso de direito tributário. 22. ed. São Paulo: Malheiros, 2003.

MARTINS, Ives Granda da Silva; BASTOS, Celso Ribeiro. Comentários à Constituição do Brasil. São Paulo, Saraiva, 1990. Tomo I, v. 6.

REALE, Miguel. Lições preliminares de direito. 27. ed. São Paulo: Saraiva, 2002. p. 303.

SIDOU, J. N. Othon. Dicionário jurídico: Academia Brasileira de Letras Jurídicas. Rio de Janeiro: Forense Universitária, 2006.

SILVA, José Afonso da. Curso de direito constitucional positivo. 18. ed. rev. e atual. São Paulo: Malheiros, 2000.

Artigo recebido em 15/02/2012 e aprovado para publicação em 17/08/2012. 